\title{
Developing an agri-food market with food security
}

\author{
O. V. Shumakova, O. N. Kryukova*, and T. G. Mozzherina
}

Omsk State Agrarian University, Faculty of Economics, Accounting and Financial Control, Omsk 644008, Russia

\begin{abstract}
The article takes into account the peculiarities of the provision process of food security under the conditions of changing policies and state strategies in this field. The peculiarities of the domestic agri-food market are determined. Specialists from the Ministry of Agriculture and Food of the Omsk Region and local municipal authorities, managers of agricultural organizations and food processing enterprises, farmers, marketing researchers, scientific staff, teachers and students of agricultural higher education institutes form the target audience of the research.
\end{abstract}

\section{Introduction}

The study of food security is rated as one of the hottest topics in current economic and technical science at a global level. Over the last few years, food security has been under constant observation at federal and regional levels. It is one of the main direction in the provision of national security to our country over the long period, a factor for the conservation of its statehood and sovereignty, a crucial component of socio-economic policies, as well as a necessary condition for the implementation of a strategic national priority such as the improvement of the life quality of Russian citizens by guaranteeing high life standards.

In fact, a stable trend towards the overconsumption and overproduction of food products can be observed. According to the esteems of the Food and Agriculture Organization of the United Nations, about one third of food products expires or gets thrown away on a global scale. Despite the abundance of food products and absence of starvation, a stable shortage can nonetheless be observed, especially as far as the consumption of specific food categories is concerned. For instance, the overall shortage of proteins in the world is estimated at 10-25 million tons per year.

The issues of food security at the same time focus the attention of researchers on the economic affordability of foodstuff, i.e. on the possibility to acquire a production of adequate quality in volumes and range which correspond to balanced consumption rates. It is thus necessary to study the economic and technological aspects of the operation of market entities and agri-food policies.

The relevance of the current research is confirmed by the fact that the balance and sustainability of the economic growth of the market becomes possible only when providing food security as a significant part of the economic and national security of any state. On the contrary, creating the conditions for a renewal and growth of the regional agri-food market while taking into account the peculiarities and features of the development of relations among its participants is a crucial strategical goal of state policies, the results of which include providing a stable demand for agro-industrial products, food security and marketing development, as well as creating the conditions for the integration, cooperation and development of the market infrastructure.

The objective of the study is represented by the search for specific mechanisms aimed at obtaining food security both at federal and regional levels in the drafts of agrifood policies.

\section{Research methods}

In order to systematize current knowledge, a set of principles, practices and methods leading to an objective view have been applied, the nature of the influence of the development stages of the agri-food market on the provision of food security has been studied.

Three main methods of scientific and educational activity were applied while carrying out the present research. Among the so-called universal methods of enquiry, analysis and generalization were applied in the characterization of certain elements of the process of security provision, including food security, on part of the state, while induction and deduction were applied in the elaboration of a mechanism which might regulate the interactions of the involved entity and can be recommended for application in other sectors.

Empirical methods were used in order to obtain practical knowledge while studying the process of the activity of the economic entities on the agri-food market based on task-oriented observation and experiments within the institutions.

All the applied methods are consistent with the following underlying principles: the principle of objectiveness (estrangement of the researcher from the object at study); the principle of continuity (research was

Corresponding author: on.kryukova@omgau.org 
carried out from 2013 to 2020); the principle of replicability (all the steps and phases of the research process can be replicated and verified by other researcher).

In order to determine the conceptual framework of the research the main research paradigms were studied: on economic and food safety, works by L.I. Abalkin, E.N. Antamoshkina, G.A. Atamanov, M. Beveridge, S. Bene, E. Biggs, I.Ya. Bogdanov, B. Boruff, E. Bruce, I.N. Buzdalov, S. Bush, V.I. Golovanov, J. Duncan, A.B. Korsak, A.I. Kostyaev, L. Kempling, Yu.I. Lyubimtsev, I.A. Morozova, H. Norbury, F. Van Ogtrop, A.A. Odintsov, N. Pauli, N.N. Potrubach, E.G. Popkova, A.N. Syomin, N.N. Skiter, L.N. Shapkina, A. Allison and others; on the formation of the organizational and economic mechanism of the creation and development of the agri-food market, works by A.I. Altukhov, G.V. Bespakhotnyi, K.G. Borodin, N.N. Vorobyov, A.G. Granberg, A.G. Zeldner, G.V. Isaeva, V.A. Klyukach, Ye.N. Krylatykh, A.S. Marshalov, A.S. Mindrin, A.S. Novosyolov, A.N. Osipov, A.G. Paptsov, P.N. Pershukevich, N.M. Rozanova, A.Z. Seleznyov, L.O. Silaeva, S.O. Siptits, I.G. Ushachyov, D.B. Khodos, R.I. Shniper and others; on the creation and development of market interrelations between the entities of the regional agri-food market, works by O.V. Borisova, N.I. Gantimurov, A.V. Glotko, N.V. Grigoryev, G.M. Gritsenko, V.P. Zotov, B.S. Koshelyov, V.A. Kundius, V.N. Papelo, E.V. Rudoy, A.T. Stadnik, V.F. Stukach, A.I. Suchkov, L.V. Tyu, V.P. Cherdantsev, I.V. Shchetinina and others.

The most fitting and applicable paradigm of scientific knowledge for the present research is represented by the conception of positive dialectical epistemology, since the object at study is a system consisting of interrelated elements and subsystems which are in opposition as far as their properties are concerned. This system has to be described in a logical and unambiguous way, which is utterly reasonable.

The theoretical and methodological foundation of the research is composed by scientific works and conceptions by both domestic and foreign scientists, in which issues related to the development of the agri-food market and to the consequences of the imposition of food security requirements to the participants of the agri-food market.

\section{The Food Security Doctrine 2020}

One of the crucial topics in the evaluation of food security and of the agro-industrial sector is most notably the field of food commodity production. The basic system of the evaluation parameters of food security is attached to the Food Security Doctrine of the Russian Federation, which was first elaborated and confirmed in 2010.

However, the analysis of the system of food security parameters as defined in the Doctrine of the Russian Federation has shown consistent flaws:

1. while dealing with national competitiveness and production sphere, the focus is mainly on performance parameters, yet the identification of factors which influence the development of such sphere should, our opinion, be practice-oriented;

2. due attention must be paid to innovation in agriculture under the conditions of the transition to innovative economy in order to render Russian production competitive;

3. specific parameters which are crucial in the evaluation of the adequacy of the same concept of food security to reality are not regulated.

This as well as others circumstances led to a redesigning of the main strategic document. In January, 2020 the new Food Security Doctrine of the Russian Federation (decree No. 20 dated January $21^{\text {st }}$, 2020) was validated by executive order of the President of the Russian Federation [1].

The updated document contains a large amount of changes due to new trends in economy: the product range used in the evaluation of food independence has been broadened; specific cultures have been added; the list of possible risks and threats to food security has been integrated (including fertility fall of agricultural lands due to misuse, veterinary and phytosanitary risks, sanitaryepidemiological and social threats); the meaning in the terminological nomenclature has been changed; the lower bounds of the level of agricultural commodity selfsufficiency have been corrected; the augmentation of export taking into account the priorities of national selfsufficiency as well as the economic and food security within the framework of the Eurasian Economic Union has been identified as a crucial topic.

The shift of focus has had an impact on the updated concept of "food security" as the state of socio-economic development of a country. Under this concept, the food independence of the Russian Federation is provided and the physical and economic affordability of food products consistent with the basic requirements is guaranteed to each and every citizen in volumes not inferior to rational food consumption rates needed for an active and healthy lifestyle. Food security is now defined as the state under which food independence is provided and the physical and economic affordability of products for each and every citizen is guaranteed in volumes needed for an active and healthy lifestyle.

At the same time, just like in the previous version of the Doctrine, the specific weight of production against the whole volume of commodities of the domestic market taking carry-over into account is used as the criterion for the evaluation of food security. The above-mentioned amendments testify that the new draft attempts to be consistent with the basic socio-economic conditions both at national and international levels, in particular for the entry in the World Trade Organization (WTO).

\section{Results}

The active and reliable involvement of all the market institutions and their representatives is needed in order to provide the food independence of the Russian Federation, which might guarantee the physical and economic affordability to each and every citizen food products which are consistent to the due requirements in volumes 
which are not inferior to rational food consumption rates. Thus the participants of the agri-food market are currently facing issues related to: the fast-paced withdrawal of the federal state from the distribution of agricultural commodities; the sharp decrease in the technical level of agricultural production; the emergence of a diversified structure of distribution channels; the appearance of a large amount of intermediary links which lead to a rise in the price of the production; the wide spreading of informal shadow relations in the interaction of the market participants; the difficulty of fixing equitable prices on the market due to administrative and other barriers; the lack of awareness of the market participants on the economic conjuncture, including possible contractors, trading range, efficient sales channels, cooperation and delivery forms; or information asymmetry which prevent the operative adoption of adequate managerial decisions in the light of the current situation. Such circumstances give rise to the inefficiency of economic relations (high transaction costs) and as a consequence the deterioration of the parameters of food security.

Therefore, the need for the expansion of research regarding the issue of increasing the level of the development of the agri-food market by creating an operative organizational and economic mechanism for the interaction of the economic entities among themselves and with the state becomes crucial. This shall enable the solution of the following tasks: increasing the satisfaction degree of the population's purchasing power as regards the main food products; increasing the volumes of production of commodities for export in other regions and countries; guaranteeing the best ratio between the level of production of agricultural commodities and the capacity of processing enterprises; enhancing the structure of intraregional and interregional ties in order to improve the provision of safe security to the population while reducing costs [2].

Different scholars consider deem it advisable to perform the evaluation of food security using as parameters the level of food independence (selfsufficiency) $o$ the region, the satisfaction of the physiological needs for food products on part of the population, the economic affordability of foodstuff [3].

A.G. Granberg states that the currently forming regional markets of agricultural commodities and food products are not stable yet, the rational equivalence between agricultural and industrial costs is compromised, administrative and criminal barriers prevent the interregional transfer of goods, the costs of the basic types of foodstuff are consistently different among regions [4, p. 18].

The economic processes of production taking place in agriculture get intertwined with all the other processes. The peculiarities of agricultural production should include [5, p. 89; 6, p. 94]: the dependence of commodity production on natural and climatic conditions; the low level of monopolization of food producers; the high capital-output ratio of the sector of dairy cattle breeding; the low level of profitability; the disparity of costs; the inappropriate state of the social environment in rural areas. The identification of trends and opportunities for strategic management shall help to promote the process for enhancing the relations between different forms of interaction on the market and to reduce the impact of risks on the agri-food market.

The orientation of production in agriculture in a region where natural and economic fertility are harmonically connected poses the optimal conditions for the breeding of animals and cultivation of agricultural crops. This becomes a crucial trend in enhancing the distribution, concentration and specialization of production and commercialization of foodstuff in the region and has a significant impact on the conditions for the development of the food market [7, p. 136].

Agri-food policies are implemented as part of the continuing agrarian reform, the aim of which is undoubtedly a sufficient food provision and food security. As stated by V.V. Putin while making a report at the $5^{\text {th }}$ Convention of the Russian Agrarian Movement, the task of the state is "to properly create a market and smoothen its disproportions".

At the present time, the share of Russian food products at retail amounts to $70 \%$. The growth of the production volumes of milk and meat shall give the chance to increase the specific weight of Russian production in the creation of milk resources up to $81.1 \%$, of meat resources up to $69.6 \%$. The share of sugar obtained from sugar beet shall reach $67.0 \%$ of the total production volume $[8, \mathrm{p}$. 168].

The introduction of sanctions towards Russian economy provoked a backlash, i.e. the total ban (until August $5^{\text {th }}, 2016$ according to the executive decree of the President of the Russian Federation No. 320 dated June $24^{\text {th }}, 2015$ [9]) of import into the Russian Federation of agricultural raw materials and foodstuff from the USA, the EU counties, Australia, Canada and the Kingdom of Norway. Since that moment the issue of import substitution has become a top-priority strategic trend of domestic agrarian policies [10]. The most problematic issue regarding the introduction on part of Russia of the food embargo is represented by a significant increase of food inflation, which results in a high risk of intensification of social strain in the society reflected by the decrease in the quality and level of life of the population [11].

A.G. Paptsov identifies the following trends in the development of the domestic food market under the conditions of the anti-sanction regime [12, p. 14]: Russian producers have not increased the volumes while at the same time increasing sale costs; an increase in the costs of most food products; an increase in the delivery of fresh products from new supplying country, most notably China, India and other states, which leads to an increase in the specific weight of low-quality imported foodstuff; a shortage of food products in the top-grade segments.

The economic space of Russia is heterogeneous as regards the density of production distribution and population density. This factor has an impact on the structure, load charge and productivity of the economy, as well as on socio-economic policies and institutional transformation in progress. Regional authorities as well as federal ministries and departments deal with the issues of 
import substitution and the difficulty of decreasing import dependence in the agro-industrial sector.

For instance, the volumes and scales of agricultural commodities production have significantly increased in the agro-industrial sector of the Omsk Region, the construction of paramount animal breeding complexes and farms using innovative technologies and the modernization and reconstruction of already functioning ones have become more intense, capital investment project are being carried out in the agricultural raw material processing sector.

Regional authorities are interested in guaranteeing a production quality in line with the global standards, thus the participant of the agri-food market, including agricultural producers, have received the necessary state support. The integration of regional agrarian market presupposes the liquidation of trade barriers, the establishment of unique standards and technologies of the certification of the production, the foundation of continuously functioning national and international (areal) organs for the control of agrarian markets, of a common institutional nucleus, of a unique infrastructure and so on [13].

Some negative trends, which are the causes for the formation of global food markets, can be currently observed in the food market $[14$, p. 53]: the priority rates of the development of certain world areas, most notably China, India and new industrial states, where an unprecedented increase of the purchasing power for new types of foodstuff with high consumption properties is provided; the rapid development of bioenergetics related to agricultural production which leads to a radical revision of the seeding structure in the main exporting countries, first of all the USA; the decline in the volume of the global food reserves due to the first two factors and by the increased frequency of natural disasters.

The process of renovation and growth of the agroindustrial sectors saw the emergence of some crucial segments in which Russia occupies a competitive position both on foreign and domestic agri-food markets, which had an impact on the commodity pattern of foreign trade. Mainly grain crops are outstanding in the export of Russia. This position is outracing the traditional leader in our country, i.e. fish and seafood.

Russia is the main exporter of grains. In the structure of food export the specific weight of oilseeds has decreased, while the share of sunflower oil has increased. Russia in self-sufficient as regards dairy products, potatoes, vegetables, pork meat and poultry. The state is making attempts at federal and local level to organize a proper sector for the intensive fattening of cattle, yet beef meat currently remain the main commodity imported in the country. In order to solve this issue, great efforts are needed over the long-time period [15].

It should be noted that food industry and agriculture in the system of national economy are rightfully considered particularly strategic and socially significant sectors, providing food security and through the latter economic and national independence and, eventually, national statehood.

\section{Conclusion}

The article faced the issue of defining the objective of the agri-food policies of the Russian Federation, which consist in the broadening of the economic and commercial potential of Russian agricultural commodity producers and others participants of the agro-industrial sector, in the increase of productivity based on the growth of the competitiveness of the production, the creation and functioning of highly developed markets in the agroindustrial sector, as well as in the increase of the affordability, reliability and security of food products for citizens in the long run.

It is reasonable to state that, in order to achieve food security both at federal and regional levers while elaborating agri-food policies, it is necessary to develop a unique integrated system consisting of interrelated elements, i.e. an organizational and economic mechanism [16]. We consider this as a system of interrelated instruments which provide the necessary conditions for an efficient functioning of the economic, social, infrastructural, agro-ecological, innovative, productionrelated, psychological, ethical, technological, juridical, political and organizational aspects of the relations among the participants within the framework of the infrastructural and institutional layout of the agri-food market taking into account their peculiarities and development characteristics [17].

The formation of the organizational and economic mechanism is aimed at achieving its main goal, i.e. an increase in the level of development of the agri-food market, and at solving the issue of providing food security, market development, reduction of costs for production and transaction costs, providing a stable demand for agro-industrial commodities, creating the conditions for the integration, cooperation and development of the market infrastructure.

This way, the definition of the peculiarities of the domestic agri-food market and the identification of the factors influencing it enable to ground and implement an efficient system of food security management. However, the current trends of cross-sectoral exchange, functional relations, clustering and broadening of the global agrifood market call for a scientifically balanced integration between the measures of state regulation and the mechanism of the market structure of the interactions between the participants of the market.

We believe the retargeting towards the formation of a comprehensive and interrelated system for the support and patronage of commodity producers and consumers of agricultural production to be necessary. This measure shall enable the implementation of the food security strategy of different regions and countries as a whole.

\section{References}

1. Food Security Doctrine of the Russian Federation: Executive Decree of the President of the Russian Federation No. 20 (21 January 2020) available at: https://www.garant.ru/products/ipo/prime/doc/73338 $425 /$ 
2. A. Stadnik, The creation of wholesale food markets as a trend in the solution of the problem of providing vegetable products and potatoes to the population of big cities, J. of Novosibirsk State Agrarian University, 1, 112-120 (2004)

3. E. Antamoshkina, G. Timofeeva, Safe security at a regional level: evaluation methodology, Economy of Russian Agriculture, 4, 61-65 (2014)

4. A. Granberg, The economic space of Russia: persistent problems, transformation processes, search for strategies, Economic Revival of Russia, 1, 16-22 (2004)

5. E. Mukhin, Evaluation of the efficiency of state support to the agro-industrial production, Economist, 4, 89 (2007)

6. I. Timonova, Calculation of the level of state support to milk producers, Economist, 5, 93-96 (2009)

7. E. Afanasyev, The role and value of the criteria in the elaboration of a strategy for the development of the agro-industrial production and food market, Nikon Readings, 17, 135-137 (2012)

8. V. Kundius, The economy of the agro-industrial sector (KNORUS, Moscow, 2016) 544 p

9. On the renewal of specific topical measures in order to provide food security in the Russian Federation: Executive Act of the President of the Russian Federation No. 320 (June 24th, 2015) Available at: http://www.garant.ru/hotlaw/federal/632900/
10. D. Nardin, I. Bobrenko, N. Goman, E. Vakalova, S. Nardina, Increasing economic efficiency of producing wheat in the West Siberia and South Ural as a factor of developing import substitution, International Review of Management and Marketing, 6.4, 772-778 (2016)

11. E. Golova, L. Goncharenko, Food provision to rural areas as a factor influencing the quality of life (according to date on the Omsk Region), Economic Relations, 3, 1939-1948 (2019)

12. A. Paptsov, The food market of Russia under the conditions of anti-sanction measures, The Agri-Food Policy of Russia, 20, 12-15 (2015)

13. Ye. Krylatykh, Agri-food systems: research on the processes of integration, competitiveness and innovation, Available at: http://www.rosnou.ru/pub/conferens/03.doc

14. T. Nabiev, Global trends in the development of the global agri-food market, Kishovarz, 2, 51-55 (2014)

15. E. Serova, The agrarian reform in Russia in the transition period, available at: http://ru-90.ru/

16. O. Shumakova, O. Kryukova, Methodological aspects of forming the vegetable micro-cluster, and its influence on sustainability of the industry, $\mathrm{J}$. of Internet Banking and Commerce, 21, 109-111 (2016)

17. O. Shumakova, O. Kryukova, The organizational and economic mechanism in the regulation of the agrifood market of the Omsk Region, Economy and Entrepreneurship, 1, 289-293 (2016) 